\title{
A Qualitative Study: Investigating EFL Learners' Self- Confidence to Decrease The Reticence in Speaking Ability
}

\author{
Ikrar Genidal Riadil \\ ikrargenidal21@gmail.com \\ Universitas Tidar, Magelang, Indonesia
}

\begin{abstract}
Language is a pivotal aspect of human being. By learning, language people can communicate with each other, get information from one to another and interact. Unfortunately, in the real condition, it is still difficult for Indonesian students to practice their English ability in daily conversation. This study deals to increase the English as a Foreign Language (EFL) students' confidence in English speaking. This research used qualitative analysis by distributing questioner. This study suggest that EFL teachers should seek ways to increase students' collaboration in the classroom to help them gain confidence in speaking. The study involved the students in the fifth semester in the English Department at Tidar University. The researcher compared the gathered data with other relevant researches and theories involved in the study. Based on the research questions, the research result shows that students' perceptions of self-confidence have a significant to decrease reticence in speaking skills. However, lecturers need to push the students in practice speaking English in front of a class, especially to improve the self-confidence when the students are communicating in English. Two research questions (RQ's) were formulated in this study. There are: (RQ1) What are the EFL students' perspectives of reticence in speaking skill? (RQ2) Do the students have high self-confidence in speaking skills? In conclusion, this article showed the results that EFL Learners' self-confidence can be decreased the reticence in speaking ability or not.
\end{abstract}

Keywords: Self-confidence, speaking ability, EFL students, qualitative study

\section{INTRODUCTION}

Language is an important aspect of human being. By learning language, people can communicate with each other, get information from one to another and interact (Riadil, 2020a). Language has a big role in human life to make a relation in their environment. Language is used widely in communication between people who do not share the same first (or even second) language (Harmer, 2007). It indicates that language is very crucial to learn in human life.

Language is an important thing to communicate with each other. However, as an international language, English is most widely used in the world for it is needed to keep up 
with the world's development. Besides, EFL students could be able to compete in the current global era. There is four skill in English; listening, speaking, reading, writing. However, one of the skills required by students is speaking, to make a communication in English. For some EFL students, mastering speaking skills is the most important aspect of learning English as a foreign language although a lot of EFL students did reticence all the time when they learned English speaking in the class.

Numerous second / foreign language (L2) researchers believe that speech abilities are an integral aspect of the education in language training and that the capacity to communicate in a foreign language is at the core of what it requires to be qualified to use a foreign language (Doqaruni, 2015). The presumption is based on two factors. First of all, our temperament, our self-image, our understanding of the environment and our capacity to think and articulate our feelings are all expressed in our spoken success in a foreign language. Being able to talk to relatives, family, guests and indeed outsiders, with their own language or even in a language that all speakers may recognize, is definitely the dream among numerous L2 learners Increasing Confidence to Decrease Reticence (Luoma, 2004). Second, the connection between both the involvement of learners in the classroom and subsequent academic success is clear (Meng, 2009). As Meng (2009) claimed that improving student speech abilities results in a "very successful learning climate." Nevertheless, the value of the skill or understanding of the ability to communicate should not be overlooked by either the instructor or the pupil (Turner, 2010).

English appears as one of international languages used to communicate among people all over the world. The use of English in the nonnative country can be divided into two English as the second language and English as a foreign language (EFL). One of the countries who applied English as foreign language is Indonesia. In EFL country, English is used for some purposes such as education, business, etc. Related to the education function, English is taught in the school started from elementary school.

Unfortunately, in the real condition, it is still difficult for Indonesian students to practice their English ability in daily conversation. Even though they have been studying English for ten years in formal junior high school, senior high school and university, they might get a good score of English in their report card, but they cannot speak English fluently yet (Musthafa, 2001). It is the fact that many English as a Foreign Language (EFL) 
teachers complain about their speaking classes in which a considerable number of students are not responding actively in speaking exercises (Abadi, 2015).

EFL students have some problems with English speaking skills. According to Astuti \& Rohim (2018), there are some difficulties to make the students feel bored when they speak English; for example, they hard to remember and pronounce words in English. EFL students seldom use English to communicate both in the classroom and the outside. However, from the internal aspect, English speaking learning makes the students feel anxious, which can make them have a high resistance when they try to speak in English.

In personality factors, self-confidence is the students' belief in their abilities in learning. However, according to Priya \& Shilaja (2016) said that the people who do not have enough self-confidence in themselves will not succeed in English speaking achievement. The lack of self-confidence can affect the students' achievement in English speaking skills.

Many factors may affect students negatively in taking part in speaking activities during the teaching experience. First, the large numbers of students which usually consist of 30-35 students or more become problematic. Such section provides fewer opportunities for them to practice speaking. Richards \& Schmidt (2010) states that class size affects the quality of instruction in which it should not exceed fifteen for most language classes.

Second, students tend to conceal their mistakes and weakness to protect them from being laughed at. As a result, they are unwilling to speak English. So, the less they practice, the less they improve their speaking skills and the more they are afraid of doing so. Last, most teachers prefer teaching grammar to productive skills such as speaking and writing. This is supported by Musthafa (2001) explained that many teachers in Asia tend to focus their teaching on grammatical items and knowledge of syntax.

In this era, numerous students of English Department at Tidar University are still shy to speak English on campus. Some of them only speak English in a special event. Sometimes, they speak English to their lecturers. Some students also speak English with their certain friends in the English Department.

In learning English, four skills should be mastered by the learners. They are listening, speaking, reading, and writing. All of them are important and interrelated each other. Riadil (2020) stated that among the four skill (listening, speaking, reading, and writing), speaking is the most important skills. Because while speaking, someone has background 
knowledge an also many of foreign language learners are interesting in learning speaking. From her point of view, it is stated that speaking is the essential skill rather than the others skills because someone who can speak in a foreign language means that she/he is knowledgeable. Moreover, according to (swary, 2014), the researcher infers that speaking also beneficial in giving us a useful valuable skill which help us to contribute in the community or even our country.

Seeing the importance of speaking skills of the foreign language in this paper in English, English learners should be able to speak English confidently and competently. However, in reality, there are a lot of English learners face the problem in speaking (Brown, 2007). Speaking problems are problems that affect someone to the poor speaking performance. Riadil (2020) stated language problems could affect to the poor academic performance of the students. Students who are deficient in speaking ability tend to lack vocabularies, grammar, and pronunciation in which belong to linguistics problems. Those problems disturb students in improving their speaking ability. Another problem which influences the students' speaking ability is a psychological problem which a problem related to the emotional and physical condition and self-productivity such as lack of selfconfident, nervous, feeling shy when speaking English.

The concern found in the teaching process was that most learners were not fully involved in the curriculum and did not talk much of the time. After casual conversations with the students, the researcher noticed that most of them had difficulties understanding English. Investigating the perceptions of students towards learning English, the researcher asked the question: "Which ability exactly are you expecting to develop the most?" the researcher noticed that most of them wished to enhance their voice, but they did not have the confidence to share their thoughts. In many terms, they tried to talk, but they had little faith to express. While teacher educators frequently educate on the basis of impersonal analyzes of the demands of their learners. And the study wanted to examine student attitudes toward speaking skills through collecting data from the questionnaires.

Afterward, the previous study of this research from one of a research entitled "INCREASING CONFIDENCE TO DECREASE RETICENCE: A QUALITATIVE ACTION RESEARCH IN SECOND LANGUAGE EDUCATION" (Doqaruni, 2015). The researcher formulates two research questions (RQ's): (RQ1) What are the EFL students' perspectives of reticence in speaking skill? (RQ2) How is the students' self-confidence in speaking ELTICS Vol.5, No.2, July 2020 
English? For that reason, this study aims to investigate the EFL students' self-confidence in speaking skills to decrease the resistance.

\section{RESEARCH METHOD}

Qualitative research was used in this research. Patton \& Cochran (2007) explained qualitative research is characterized by its aims, which relate to understanding some aspects of social life, and its methods which generate words, rather than numbers, as data for analysis. Qualitative research is understanding of social phenomenon based on participant's point of view. The data were collected by giving questionnaires to participants. The data collection procedures of this study were started by giving the questionnaire, asking the participants to fill in the questionnaire and finally the researcher compiled the questionnaire that had been answered.

This method was influenced by (Cam and Tran, 2017). After the data had been collected, it would be analyzed and recognized. Like what Cam and Tran (2017) stated that the questionnaire was a quite useful collection method because researcher could reach many participants and respondents in a short time and it did not need cost so much.

This study aimed to investigate EFL students' self-confidence in speaking skills. The researcher tries to find the student's awareness based on their circumstances of selfconfidence to finding the level of self-confidence in teaching speaking English as a foreign language for students in the university. This study was conducted by using a descriptive qualitative approach, by distributing the questioner to the students. The participants of this research were the students in the 5th semester of the English Department at Tidar University, which consists of 20 respondents.

To begin the study, the researcher described to the respondents what self-confidence is. Formerly, the researcher looked for and chose the participants of this research. Afterward collecting the objects of this study, the researcher identified the result of the students' questioner which adapted from Caganova (2008) about self-confidence, of the selected objects that would be analyzed. In the next part of the research process, the learning and teaching process was analyzed by using the theories. Firstly, the researcher looked for some problems in the students' speaking skills. Secondly, the researcher's findings were analyzed and classified into the purposes, and the perspective of the students. Thirdly, the findings of classifications were defined, explained, and analyzed the 
students' self-confidence in speaking skills. Those steps were to answer the research questions in this study.

\section{RESULTS AND ANALYSIS}

This part discusses the results of this study. It consists of two sections, namely the explanation of the EFL students' perspectives of reticence in speaking, do the students have high self-confidence in speaking skills? Especially in 5th-semester students in English department at Tidar University.

\subsection{The EFL Students' Perspectives Towards Self-confidence in Learning English}

\subsubsection{Students' interest in learning English}

The students' interest in learning English can be the factor for influence the students' reticence in speaking. This data was conducted by the researcher in 5thsemester students in the English department of Tidar University. The table below shows the students' interest in learning English in 5th-semester students in the English department of Tidar University, which consists of 20 respondents.

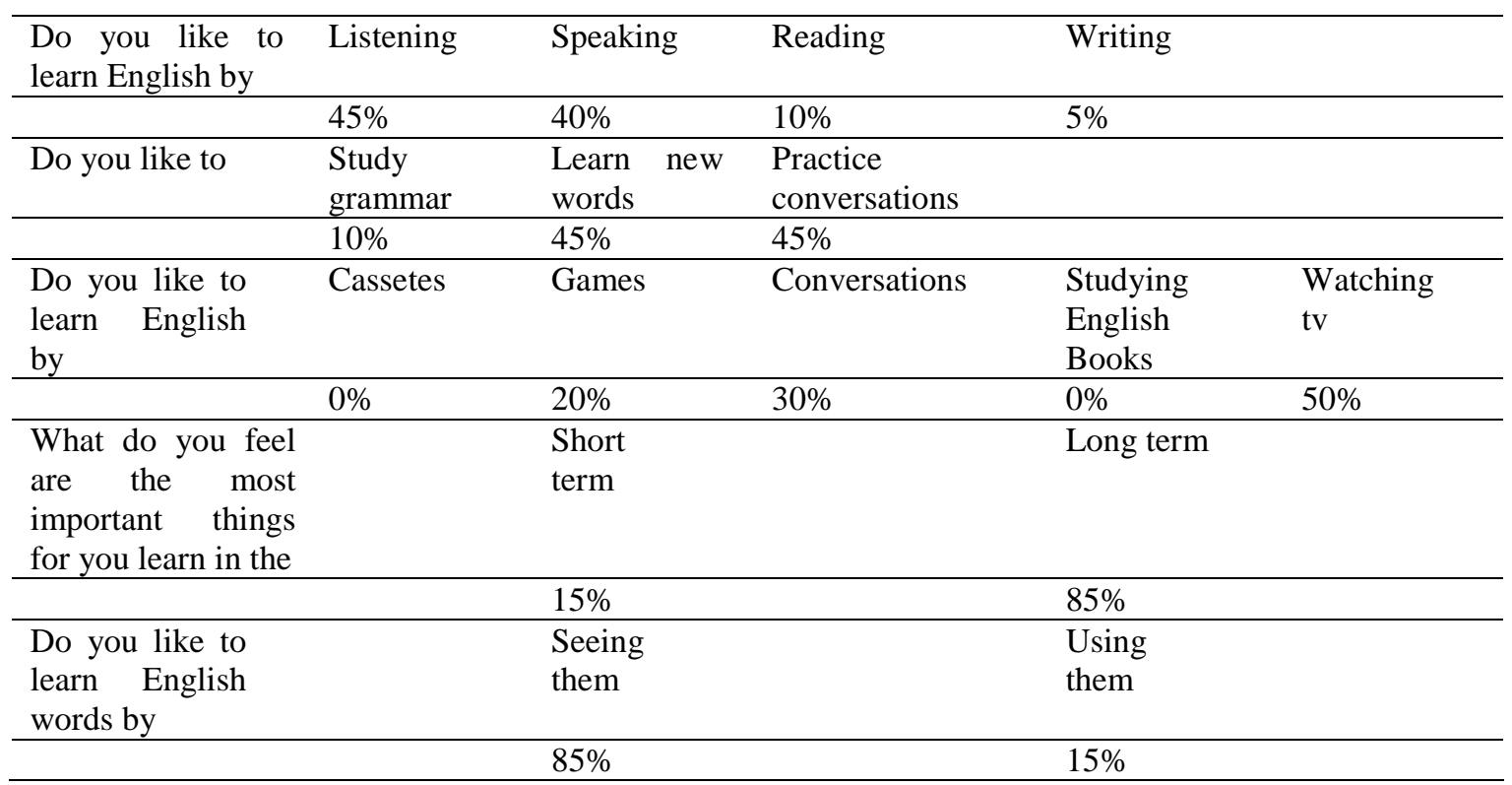

Based on the table above, from the first question, 9 students interest in listening with $45 \%$ and 8 students who interest in speaking with $40 \%, 2$ students who interest in reading with $10 \%$, and 1 student who interest in writing. It means that most of the students like listening even though one student difference.

In the second question, 9 students like to learn English to learn words and for conversation, both of those with $45 \%$. Also, only 2 students who like to learn ELTICS Vol.5, No.2, July 2020 
English to study grammar with $10 \%$. It means that most of the students like to learn English for the communication because of only a few who like to study English to study grammar.

In the third question, from 20 students in the class, there are a half of students who like learn English by watching tv with 50\%, 6 students who like learn English by using a conversation with $30 \%$, and 4 students who like learn English by playing games with $20 \%$. However, no student likes to learn English by cassettes and studying English books. It means that most of the students are like to learn English in fun ways. In the fourth question, from 20 students, 17 students feel that the most important thing to learn English is in the long term with 85\%, and 3 students who chose in the short term with $15 \%$. In the fifth question, from 20 students, 17 students with $85 \%$ who like to learn English by using them. However, 3 students with 15\% who like learn English by seeing them. It means that, most of the students are learn English not only by seeing them but also using them, for example the can use English for communication.

\subsubsection{The students' perception of the method in learning English speaking}

The students' perception of the method in learning English speaking can be the factors for influence the students' reticence in speaking. This data was conducted by the researcher in 5th-semester students in the English department of Tidar University.

\begin{tabular}{lcc} 
& Yes & No \\
\hline $\begin{array}{l}\text { Do you like to learn by talking to } \\
\text { friends in English }\end{array}$ & $75 \%$ & $25 \%$ \\
\hline $\begin{array}{l}\text { Do you like to learn English by talking } \\
\text { in pairs }\end{array}$ & $85 \%$ & $15 \%$ \\
\hline Do you speak English out of the class & $70 \%$ & $30 \%$ \\
\hline
\end{tabular}

The table above shows the students' perception of the method in learning English speaking in 5th-semester students in the English department of Tidar University, which consists of 20 respondents.

Based on the table above, from the first question, from 20 students who fill the questioner, 15 students who like to learn English speaking by talking to friends in English with $75 \%$, and 5 students who chose no with $25 \%$. In the second question, from 20 students who fill the questioner, 17 students who like to learn English by talking in pairs with $85 \%$, and 3 students who chose no with $15 \%$. In the third question, from 20 students who fill the questioner, 14 students speak English out of the class. However, 6 students didn't speak English out of the class. 
Those result questioners mean that, most of the student's interest in speaking for communication in daily life, for example with their friends. Because most of them answered yes for each question.

3.1.3, Students' perception of collaboration in learning English speaking activities

The students'perceptions of collaboration in learning English speaking activities can be the factors for influence the students' reticence in speaking. This data was conducted by the researcher in 5th-semester students in the English department of Tidar University.

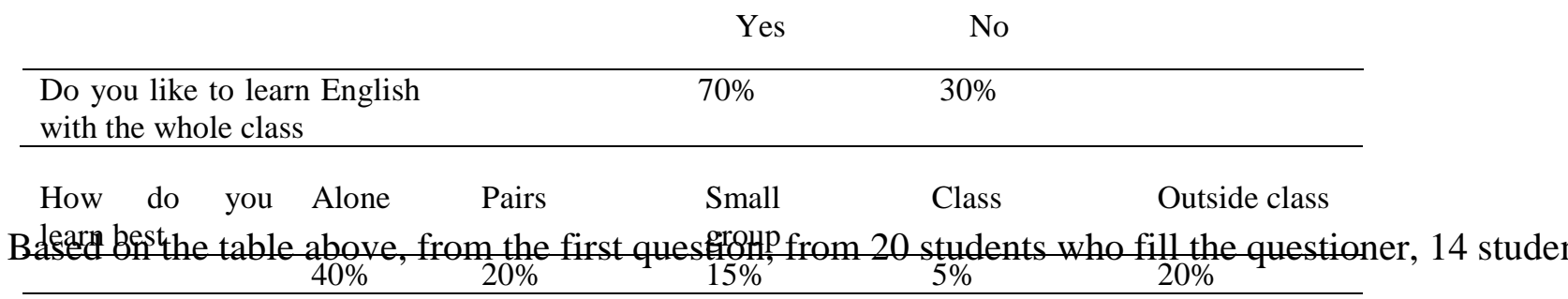

Also, in the second question, the researcher found the result of the students' perception about collaboration in learning English speaking activities, 8 students learn best when they are alone with $40 \%, 4$ students learn best when they are learning in pairs and outside class, with 20\%. Also, 3 students learn best when they are in a small group with $15 \%$, and 1 student in class with $5 \%$. It means that most of the students in English department of Tidar University, feel more confident and produce a maximum achievement when they learn English speaking alone.

\subsection{Do the students have high self-confidence in speaking skills?}

To know the students in the 5th semester in the English department of Tidar University have high self-confidence or not in speaking English, the researcher has found from the research questioner. The table below shows the students' in 5th-semester students in the English department of Tidar University self-confidence, which consists of 20 respondents.

\begin{tabular}{lcc} 
& Yes & No \\
\hline $\begin{array}{l}\text { Do you feel happy when you } \\
\text { speak English }\end{array}$ & $90 \%$ & $10 \%$ \\
\hline $\begin{array}{l}\text { Do you look for chances to } \\
\text { speak English }\end{array}$ & $85 \%$ & $15 \%$ \\
\hline $\begin{array}{l}\text { Do you have enough } \\
\text { confidence to speak to a group } \\
\text { of people in English }\end{array}$ & $45 \%$ & $55 \%$ \\
\hline $\begin{array}{l}\text { Do you feel relaxed when you } \\
\text { speak in English }\end{array}$ & $45 \%$ & $55 \%$ \\
\hline
\end{tabular}

Based on the table above, from the first question, 14 students like to learn English with the whole class with $70 \%$, and 6 students who chose no with $30 \%$. In the second ELTICS Vol.5, No.2, July 2020 
question, 17 students look for chances to speak English with 85\%, and only 3 students who chose no with $15 \%$. In the third question, 11 students don't have enough confidence when they speak to a group of people in English with 55\%. However, 9 students have enough confidence in this case. For the last question, 11 students feel unrelaxed when they speak in English with 55\% and only 9 students who feel relaxed when they speak in English.

From the last two questions of the questioner, those mean that most of the students in the 5th semester in the English department of Tidar University, still have low selfconfidence in learning English speaking.

\section{CONCLUSION}

Based on the finding and discussion, and also from the results of two questioners, the researcher concludes that most students like to learn in speaking. Most of the students like to learn to speak in a fun way, such as practicing by using conversation or by watching television using English. In this study, the researcher also found that most students have an interest in speaking in English, however, they still have low self-confidence to using that. The EFL students also feel unrelaxed and unconfident because in Indonesia we only use English in the English class.

In this case, the 5th semester students in the English department of Tidar University is also using English not in their daily life for communication but only use English in the class or around the faculty. So, most students don't have a high selfconfidence when they speak English for communication.

In conclusion, the finding and discussion of this study can suggest that the lecturer should seek ways to include EFL students' interest, collaboration, and students' perception in the subject language as part of their curriculum design to help them gain confidence in learning English speaking. Through this study, extra-talk practices have been integrated into the classroom to improve participant success in terms of peer-togroup learning. Though some teacher-centred teaching, which usually requires little involvement in English, is the most prevalent in EFL classrooms, this research has shown that the teaching approach stresses peer cooperation as a way to improve the capacity of peers to the students to speak is likely to result in confidence. The results of this study indicate that foreign language (FL) teachers will explore opportunities to incorporate student cooperation in the subject language as part of their instructional design to help them develop interest in speaking foreign language (FL). 


\section{REFERENCES}

Abadi, C. P. (2015). Developing Speaking Skill in EFL English Course. Journal on English as a Foreign Language, 5(2), 133. https://doi.org/10.23971/jefl.v5i2.373

Astuti, R. P., \& Rohim, A.-. (2018). The Effect of Student Presentation on the Eleventh Grade Student's Speaking Skill at SMA Negeri 24 Kabupaten Tangerang. Globish: An English-Indonesian Journal for English, Education, and Culture, 7(2).

Brown, H. D. (2007). Teaching by Principles, Second Edition. Teaching by Principles An Interactive Approach to Language Pedagogy.

Caganova, D. (2008). Syllabus design. Annals of DAAAM and Proceedings of the International DAAAM Symposium. https://doi.org/10.2307/329263

Cam, L., \& Tran, T. M. T. (2017). An evaluation of using games in teaching English grammar for first year English-majored students at Dong Nai Technology University. International Journal of Learning, Teaching and Educational Research, 16(7), 55-71. Retrieved

from https://pdfs.semanticscholar.org/ea44/48f1c6cbb8dab7420abbd20a993a86728206.pdf Doqaruni, V. R. (2015). Increasing Confidence to Decrease Reticence: A Qualitative Action Research in Second Language Education. The Canadian Journal of Action Research, 16(3), 42-60.

Harmer, J. (2007). The Practice of English Languag Teaching. 394-409.

Luoma, S. (2004). Assessing speaking Cambridge University Press. Módulo Psicopedagogía. México: CECTE-ILCE.

Meng, F. (2009). Encourage Learners in the Large Class to Speak English in Group Work. English Language Teaching, 2(3), 219-224.

Musthafa, B. (2001). Communicative language teaching in Indonesia issue of theoretical assumption and challenges in the classroom practice. Journal of Southeast Asian Education, 2.

Quinn Patton, M., \& Cochran, M. (2007). A Guide to Using Qualitative Research Methodology. In Medecins Sans Frontieres. Retrieved from http://msf.openrepository.com/msf/handle/10144/84230

Riadil, I. G. (2019). The EFL Learner's Perspectives About Accuracy, Fluency, and Complexity In Daily Routines. Journal of Research on Applied Linguistics, 
Language, and Language Teaching, 2(2), 160-166.

Riadil, I. G. (2020). A Study of Students' Perception: Identifying EFL Learners' Problems in Speaking Skill. International Journal of Education, Language, and Religion, 2(1), $31-38$.

Riadil, I. G. (2020). AN ANALYSIS OF ENGLISH MODALS IN EDUCATIONAL ESSAYS OF ' SHERRY JOHNSON ' AND ' TAMJID MUJTABA .' Jurnal Pendidikan Bahasa, 9(1), 131-142.

Riadil, I. G. (2020). Tourism Industry Crisis and its Impacts: Investigating the Indonesian Tourism Employees Perspectives' in the Pandemic of COVID-19. Jurnal Kepariwisataan: Destinasi, Hospitalitas Dan Perjalanan, 4(2), 98-108.

Richards, J. C., \& Schmidt, R. (2010). Longman dictionary of language teaching \& applied linguistics. In Proceedings of the 21st Asian Pacific Weed Science Society (APWSS) Conference, 2-6 October 2007, Colombo, Sri Lanka. Retrieved from http://images.pcmac.org/Uploads/JeffersonCountySchools/JeffersonCountySchools/D epartments/DocumentsSubCategories/Documents/English - Dictionary of Language Teaching and Applied Linguistics.pdf

Sathiya Priya, T., \& Shilaja, C. L. (2016). Collaborative learning. Man in India. https://doi.org/10.5367/000000000101294922

Swary, D. (2014). A Study of Students' Problems in Learning Speaking English At the Second Grade of Faculty of Tarbiyah and Teaching Science of Syekh Nurjati State Institute for Islamic Studies. Thesis, (Problem In Learning Speaking), 67.

Tang, F. (1997). A course in language teaching: Practice and theory. System. https://doi.org/10.1016/s0346-251x(97)84229-7

Turner, J. (2010). The impact of pupil-set targets on achievement in speaking: An action research project involving a mixed-sex Year 9 German class. Journal of Trainee Teacher Educational Research, 1, 1-34. 